\title{
Scale-dependent natural variation in larval nutritional reserves in a marine invertebrate: implications for recruitment and cross-ecosystem coupling
}

\author{
L. Giménez ${ }^{1, *}$, G. Torres ${ }^{1,4}$, A. Pettersen ${ }^{1,5}$, M. T. Burrows ${ }^{2}$, A. Estevez ${ }^{3}$, \\ S. R. Jenkins ${ }^{1}$ \\ ${ }^{1}$ School of Ocean Sciences, Bangor University, Anglesey LL59 5AB, UK \\ ${ }^{2}$ Scottish Marine Institute (SAMS) Oban, Argyll PA37 1QA, UK \\ ${ }^{3}$ IRTA-Sant Carles de la Rápita, Ctra. Poble Nou Km 6, 43540-Sant Carles de la Ràpita, Tarragona, Spain \\ ${ }^{4}$ Present address: Alfred Wegener Institut, Helmholtz-Zentrum für Polar- und Meeresforschung, Biologische Anstalt Helgoland, \\ 27498 Helgoland, Germany \\ ${ }^{5}$ Present address: School of Biological Sciences, Monash University, Melbourne, Victoria 3800, Australia
}

\begin{abstract}
In species with complex life cycles, laboratory studies have shown that variations in the traits of settling larvae can affect post-settlement survival and influence recruitment and benthic-pelagic coupling. However, we still know little about the magnitude and spatial scale of natural trait variation. We studied spatial variation in body size and nutritional reserves (carbon, nitrogen and lipids) of settled cyprids of the barnacle Semibalanus balanoides along the coast of West Scotland. We quantified variation among regions (north vs. south: range $\sim 700 \mathrm{~km}$ ), locations $(\sim 50 \mathrm{~km})$, shores $(\sim 10 \mathrm{~km})$ and within shores $(\sim 10 \mathrm{~m})$. We also evaluated trait responses to gradients in chlorophyll and shore openness and compared swimming vs. settled cyprids in order to infer the likely influence of costs of substratum search on trait variation. Variability between regions was large, with higher trait values (e.g. carbon cyprid ${ }^{-1}: 35$ to $50 \%$ higher) in the north. Most traits correlated negatively with pelagic chlorophyll a (a proxy for larval/juvenile food availability); this counter-gradient pattern suggests an adaptive role of increased reserves, buffering benthic juveniles from low food availability during the critical early post-settlement period. Body size and nitrogen content correlated positively with shore openness; lower than expected carbon content suggest increased costs of substratum search on open shorelines. Higher nitrogen content but lower percent carbon was found in settled vs. swimming larvae, suggesting costs of substratum search at the time of settlement. Overall, we uncovered the spatial scales at which trait variation, shaped by pelagic processes, can affect post-metamorphic survival, recruitment and benthic-pelagic coupling.
\end{abstract}

KEY WORDS: Benthic-pelagic coupling $\cdot$ Larval ecology $\cdot$ Life history $\cdot$ Recruitment $\cdot$ Settlement

\section{INTRODUCTION}

Most ecological studies focus on numerical effects in order to understand patterns of species distribution and population dynamics; they tend to ignore potential effects of intra-specific phenotypic variation (IPV) across or within life stages. There is, how-

${ }^{*}$ Corresponding author: l.gimenez@bangor.ac.uk ever, a growing body of work recognising the importance of phenotypic differences: at the level of populations, IPVs arising during early development are responsible for delayed effects on survival at late stages of organisms (Benton et al. 2005, Bolnick et al. 2011) that are strong enough to drive the dynamics of adult populations (Sinervo et al. 2000, Beckermann

() The authors 2017. Open Access under Creative Commons by Attribution Licence. Use, distribution and reproduction are unrestricted. Authors and original publication must be credited. 
et al. 2003, Marshall \& Morgan 2011, Van Allen \& Rudolf 2015). In addition, at the level of communities, several mechanisms have been identified by which IPV can affect structure or dynamics (Bolnick et al. 2011).

At present, we know that delayed trait-mediated effects originate from phenotypic plastic responses or from phenotypic selection and evolution (Bolnick et al. 2011, Ellner 2013). For instance, laboratory experiments using marine invertebrates have shown that environmental conditions experienced by larval stages modify body size or the level of nutritional reserves of metamorphosing larvae and then affect the performance of post-metamorphic stages (Pechenik et al. 1998, Pechenik 2006, Podolsky \& Moran 2006, Marshall \& Morgan 2011, Torres et al. 2016). However, these laboratory experiments may have manipulated the larval environment to extreme conditions, thereby creating extreme physiological phenotypes that may be rare under natural conditions. By contrast, we still know little about whether the amount of natural variation in larval nutritional reserves is sufficient to affect post-metamorphic performance (but see Jarrett 2003, Phillips 2006, Giménez 2010, Rey et al. 2016). There are several hurdles hampering our understanding of the effects of larval reserves on recruitment in marine invertebrates. First, variation in larval reserves must be evaluated at multiple scales: variation is expected to be scale-dependent in time and space (McLachlan \& Ladle 2011, Sotka 2012, Todd et al. 2012) because it will originate from biotic and abiotic processes operating at a hierarchy of scales (Wiens 1989, Levin 1992, Chave 2013). Second, nutritional reserves must be quantified in tiny larvae that are difficult to collect in sufficient numbers at specific stages of the life cycle. However, if larval reserves are quantified at the appropriate life history transitions, we can increase our understanding of how they affect crossscale as well as cross-habitat processes that are known to affect populations and communities (Menge et al. 2003, Schreiber \& Rudolf 2008). At transitions such as metamorphosis, many species undergo habitat shifts as well as changes in dispersal capabilities. For instance, barnacles are representative of organisms connecting populations and ecosystems through dispersive larval stages. Barnacles develop through larval stages that link the coastal ocean with benthic habitats (Roughgarden et al. 1988, Levin 2006). The early larval stages (nauplii) spend $\sim 4$ to 5 wk feeding and growing in the coastal-ocean waters while the cyprid non-feeding larvae are specialised to search for, settle and metamorphose on appropriate hard substratum habitats. The larval pool produced by a population is likely to experience variation in physical and biotic conditions over a wide range of spatial scales. Hence, larval nutritional reserves at the time of colonization of rocky habitats are likely to reflect variation in pelagic conditions, for example in food availability. In addition, the nutritional reserves of settling cyprids depend on the time required to find an appropriate substratum for settlement, as cyprids consume reserves over that period. Cyprid physiological traits can define the settlement success (Tremblay et al. 2007), metamorphic success and early post-metamorphic survival (Thiyagarajan et al. 2005) as well as the number of individuals recruiting to the reproductive cohorts (Torres et al. 2016). Hence, quantifying scale-dependent patterns of nutritional reserves at the time of habitat colonization is critical to understanding causes and ecological consequences of phenotypic variation on recruitment.

Here, we report on variation in nutritional reserves of settling cyprids of the intertidal barnacle Semibalanus balanoides over a wide range of scales $(\sim 10 \mathrm{~m}$ to $>700 \mathrm{~km}$ ) along the west coast of Scotland (see Fig. 1). We quantified scale-dependent patterns in several metrics of larval nutritional traits (body size, mass, elemental carbon and nitrogen as well as major lipid classes) in newly settled larvae (=colonisers) as a way to identify scales at which phenotypic variation may impact ecological processes. In addition, we explored if such patterns would respond to a hierarchy of environmental factors that are likely to affect coloniser traits at different scales. We then analysed the trait responses in the light of existing physiological information in order to infer potential ecological processes driving phenotypic responses. First, we evaluated trait responses to a regional scale gradient in pelagic chlorophyll a ( $\mathrm{chl}$ a) $(\sim 700 \mathrm{~km})$ on the west coast of Scotland characterised by a decreasing trend from north to south (see Fig. 1). Chl a is a proxy for the food (microalgae) available for growth of feeding nauplii and juveniles. We hypothesised that coloniser traits would reflect variations in food availability with increased reserves in the south; other patterns may reflect the prevalence of compensatory adaptive processes. Second, we studied the response of coloniser traits to coastal openness. Coastal openness varies at the shore scale (10 to $50 \mathrm{~km}$ ) according to the fjordic nature of the Scottish coast. It may indirectly influence coloniser phenotypes by modifying the water column structure and environmental conditions during feeding stages, or by changing the time invested in searching for a suitable settlement site. For example, in fjords, non-feeding larvae should quickly 
reach any surrounding rocky habitat, while in open shores, larvae may take much longer to reach the shore; some evidence of such processes is found in comparisons of settlement rates in West Scotland vs. open shores of eastern England (Kendall et al. 1982). Third, we evaluated differences between swimming non-feeding larvae and colonisers as a way to infer if processes occurring in the near-shore can drive coloniser phenotype. Our analysis enabled us to identify critical scales at which natural variation in larval reserves are likely to impact recruitment and cross-ecosystem processes as well as derive a series of testable mechanisms driving such variation.

\section{MATERIALS AND METHODS}

\section{Model species and biophysical setup}

Semibalanus balanoides is a boreal marine barnacle, common in the north Atlantic coastal waters of Europe and North America. The nauplius larvae feed and grow for several weeks in the water column be- fore moulting to the non-feeding cyprid stage, which searches for an appropriate habitat in which to settle. Search time is limited by energy costs (Lucas et al. 1979) and extended search times result in the loss of lipids. In addition, after settlement and metamorphosis to the juvenile stage, barnacles must survive without food for a minimum of 2 to $5 \mathrm{~d}$ post-metamorphosis (Rainbow \& Walker 1977). Both post-settlement metamorphic success and larval growth correlate with cyprid organic content (Jarrett 2003). Variation in both barnacle density and post-metamorphic growth explain patterns of juvenile mortality because resource limitation, and possibly intraspecific competition, are set by barnacle density as well as body size (Jenkins et al. 2008, Giménez \& Jenkins 2013); both body size and abundance determine the number of individuals reaching the reproductive stages.

The west coast of Scotland is characterised by a system of fjords and islands dominated by rocky substratum in the intertidal zone (Fig. 1). Studies of surface temperatures do not report latitudinal thermal gradients (Burrows et al. 2010, Bresnan et al. 2015) and satellite data obtained for the sampling period
Fig. 1. Location of sampled shores (S1 to $\mathrm{S} 12$ ) on the west coast of Scotland aggregated by region and averaged estimates from satellite chl a from MODIS. Circles delineate sectors used to estimate average chl a levels associated with each shore; these averages were used in subsequent analyses

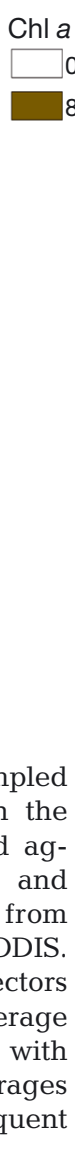

2011
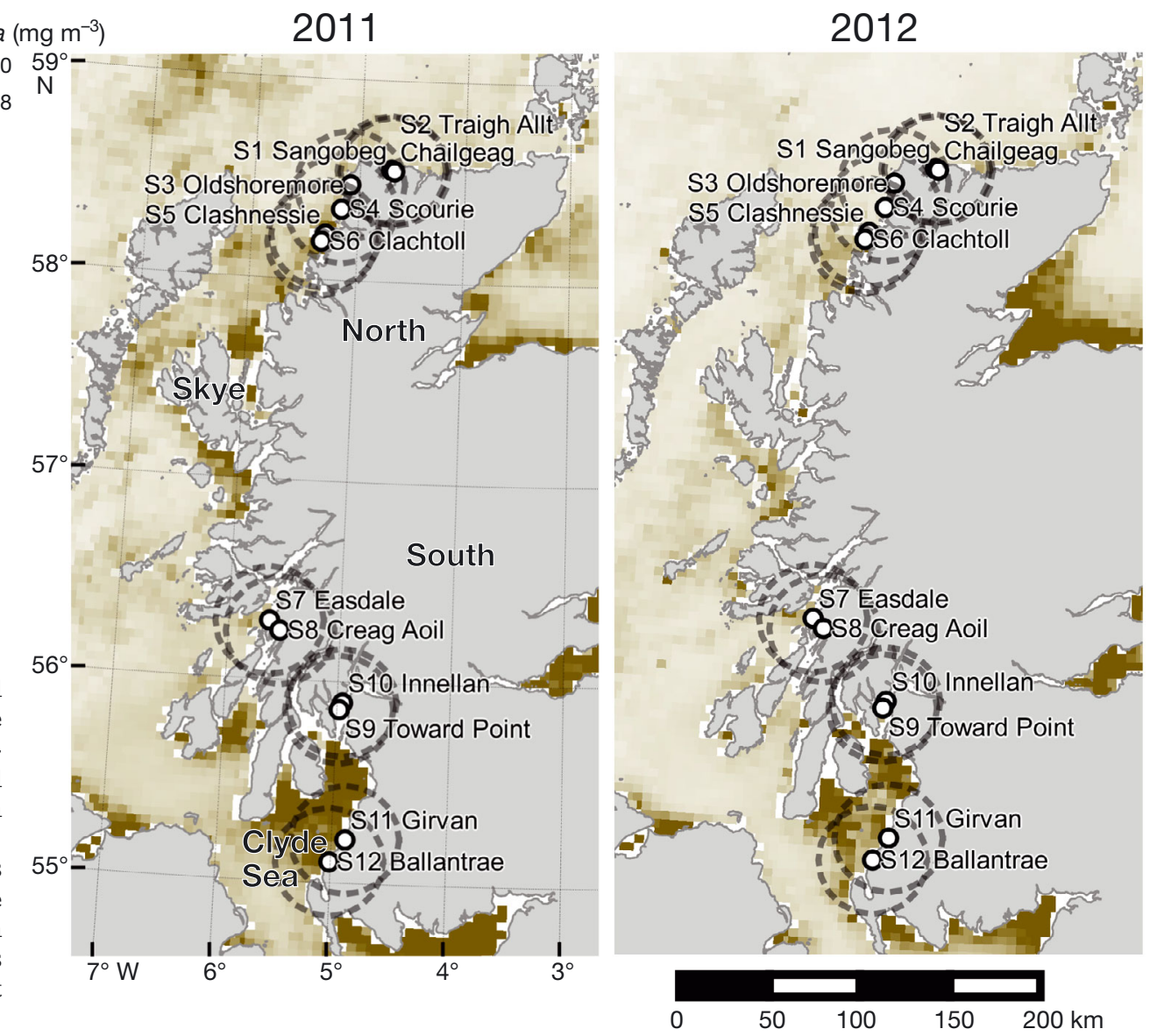
did not show gradients in temperature (see Fig. S1 in the Supplement at www.int-res.com/articles/suppl/ m570p141_supp.pdf). There is, however, a strong and temporally consistent regional gradient in $\mathrm{chl} a$ (Burrows et al. 2010), an indicator of phytoplankton biomass available for plankton grazers such as the larvae of $S$. balanoides. Burrows et al. (2010) reported low average levels of chlorophyll $\left(<1.5 \mathrm{mg} \mathrm{m}^{-3}\right)$ north of the island of Skye (Fig. 1), especially at the northernmost portion of the Scottish coast $\left(\sim 1 \mathrm{mg} \mathrm{m}^{-3}\right)$. By contrast, average chl a levels were higher $(>1.5 \mathrm{mg}$ $\mathrm{m}^{-3}$ ) towards the south, especially in the Clyde Sea and further south towards Loch Ryan $\left(>2 \mathrm{mg} \mathrm{m}^{-3}\right.$ ). This was confirmed by satellite data (Fig. 1) corresponding to our study period $(2011,2012)$, showing a consistent north-south gradient in chl a with low average values $\left(\sim 1 \mathrm{mg} \mathrm{m}^{-3}\right)$ in the north and northwest and high values in the Clyde Sea $\left(>5 \mathrm{mg} \mathrm{m}^{-3}\right)$. The chl a levels show seasonal patterns with a peak in spring, as shown when satellite-based chl a levels were estimated around the sampled locations (Fig. S2). Between February and April, when feeding larval stages develop, northerly locations showed levels of chl a consistently less than $4 \mathrm{mg} \mathrm{m}^{-3}$ (in the range found by Bresnan et al. 2015 for the period 2003 to 2012) contrasting with higher levels in much of the south. Chlorophyll levels varied between 4 and $20 \mathrm{mg} \mathrm{m}^{-3}$ in the Clyde Sea (locations S2 and S3, Fig. 1) but were lower in Argyll (location S1: $<4 \mathrm{mg}$ $\mathrm{m}^{-3}$ ). Long-term satellite data (past $14 \mathrm{yr}$; see Fig. S3) suggests that the north-south spatial patterns in chlorophyll levels, and presumably food availability, have been consistent over several generations of barnacles.

\section{Sampling design}

Sampling was carried out in spring 2011 and 2012, when the non-feeding cyprid larvae of $S$. balanoides colonise intertidal rocky shores. There were 4 sampling trips; 2 in 2011 (8 to 15 April and 3 to 15 May) and 2 in 2012 (10 to 17 April and 25 April to 1 May). Larvae were collected in 2 regions, north and south of the island of Skye (Fig. 1a). At each region, 3 wave-exposed locations were selected at random from a larger pool of locations. At each location, 2 shores (intertidal rocky habitats of ca. 50 to $100 \mathrm{~m}$ extension) were sampled (total: 12 shores). Shores were separated by a minimum of $\sim 2 \mathrm{~km}$ and a maximum of $\sim 25 \mathrm{~km}$; shores from different locations were separated by a minimum of $\sim 35 \mathrm{~km}$ and a maximum of $\sim 95 \mathrm{~km}$. On each shore, samples were taken at 4 stations, located at approximately mid-shore level at the centre of the distribution of $S$. balanoides, where larval colonization is at its peak. Stations were randomly selected over a minimum of $50 \mathrm{~m}$ of shoreline.

At each station, we collected larvae that colonised rocks only during the previous high tide in order to minimise effects of post-settlement age on nutritional reserves. We visited each shore during evening/night low tide and cleared the substratum of all biota (predominantly adult $S$. balanoides) in 3 to 4 quadrats (usually $0.5 \times 0.5 \mathrm{~m}^{2}$ ) per station (stations were separated ca. 10 to $20 \mathrm{~m}$, while quadrats were separated by 1 to $2 \mathrm{~m}$ ). To ensure that all quadrats were clear of any new barnacle recruits, we scraped the rock surface repeatedly with metal and plastic brushes and thereafter checked the bare rock with the help of magnifying glasses. During low tide the following morning, all quadrats were revisited and colonisers collected using mounted needles. Collection was carried out under magnifying glasses to ensure that individuals were not damaged during collection. All individuals from quadrats belonging to the same station were pooled, stored in $1.5 \mathrm{ml}$ micro-centrifuge tubes with $500 \mu \mathrm{l}$ filtered seawater and immediately frozen in liquid nitrogen.

Each of the 4 sampling trips took $8 \mathrm{~d}$. Simultaneous sampling of all 12 sites per trip was not possible due to the long distance among locations from different regions. In order to minimise confounding temporal and spatial patterns, we constrained the sampling period of the 12 shores to a period of $8 \mathrm{~d}$ corresponding to 1 spring tide period. A total of 2 shores location ${ }^{-1}$ were visited simultaneously in the same night and following day. Potential confounding of temporal and spatial patterns were further controlled by sampling locations from the southern region at the beginning and end of each trip (see Table S1 in the Supplement).

Swimming non-feeding larvae were collected at high tide $1 \mathrm{~d}$ before collection of colonisers (settled larvae). Swimming larvae were collected at 1 shore location $^{-1}$ with a plankton net (diameter $=0.5 \mathrm{~m}$, mesh size $200 \mu \mathrm{m})$.

\section{Body size, mass and elemental composition}

We used body length, dry mass and elemental carbon and nitrogen as larval traits reflecting the total nutritional reserves of a larva. In other crustacean larvae, elemental carbon reflects the amount of lipids, while nitrogen reflects the amount of proteins (Anger \& Harms 1990). The high proportion of lipids found in barnacle cyprids is reflected in a high per- 
centage carbon ( $>45 \%$; Harms 1987). The analysis of elemental composition has the advantage that low numbers of larvae are required to obtain reliable estimates, enabling a proper quantification of nutritional reserves at several spatial scales.

All larvae were examined under a dissecting microscope to ensure that only intact individuals of $S$. balanoides were used for subsequent analyses. Those confirmed as $S$. balanoides were then measured (body length) under the microscope. For dry mass and elemental composition (carbon and nitrogen), 20 to 30 individual cyprids from each of the 4 stations per shore were used to generate 4 replicate estimates (i.e. individuals were pooled at each replicate station). Sample processing followed Anger \& Harms (1990); following measurement of size, individuals were rinsed in distilled water, blot dried with filter paper and placed in an aluminium cartridge. Samples were then freeze-dried (Edwards Supermodulyo $12 \mathrm{k}$ freeze-drier) and weighed using a microbalance (Mettler Toledo, precision $=1 \mu \mathrm{g}$ ) to determine dry mass. Carbon and nitrogen content was determined using a CHNS-O Analyser (Thermo Electron Flash EA 1112 series).

\section{Lipid analyses}

Each lipid sample consisted of ca. 80 to 300 larvae collected at a specific shore. Total lipids from larval tissues were extracted in chloroform:methanol (2:1, $\mathrm{v}: \mathrm{v})$ using the method of Folch et al. (1957) and quantified gravimetrically after evaporation of the solvent under a stream of nitrogen followed by vacuum desiccation overnight. Total lipids were stored in chloroform:methanol $\left(2: 1,20 \mathrm{mg} \mathrm{ml}^{-1}\right)$ containing $0.01 \%$ butylated hydroxytoluene (BHT) at $-20^{\circ} \mathrm{C}$ until final analysis.

Lipid class separation was performed by highperformance thin-layer chromatography (HPTLC) following Olsen \& Henderson (1989). Approximately $10 \mu \mathrm{g}$ of lipid was applied as a $2 \mathrm{~mm}$ streak and the plate developed to two-thirds distance with methyl acetate/isopropanol/chloroform/methanol/0.25\% aqueous $\mathrm{KCl}$ (25:25:25:10:9, by vol.), to separate polar lipid classes, and then fully developed with isohexane/diethyl ether/acetic acid (85:15:1, by vol.). After separation, bands were identified by charring the plates at $100^{\circ} \mathrm{C}$ for $30 \mathrm{~min}$ after spraying with $3 \%$ $(\mathrm{w} / \mathrm{v})$ aqueous cupric acetate containing $8 \%(\mathrm{v} / \mathrm{v})$ phosphoric acid and quantified by scanning densitometry using a GS 800 calibrated densitometer (Bio-Rad Laboratories). The identities of individual lipid classes were confirmed by comparison with authentic standards.

\section{Data analysis}

The objectives were addressed through mixed modelling and variance components (Galecki \& Burzykowski 2013, Zuur et al. 2009), using R (R Core Team 2013) and the 'nlme' package (Pinheiro et al. 2015). Model selection was carried out through Akaike's information criterion (AIC), and hypothesis testing through likelihood ratio (LR) tests. Models were ranked according to $\mathrm{AIC}_{i}$ the model with the lowest AIC was compared to the other models using the differences between the AIC scores ( $\triangle \mathrm{AIC})$. When $\Delta$ AIC $>3$, the model with lower AIC was selected. When $\triangle$ AIC $<3$, models were compared with LR tests (if models were nested in each other); when models differed significantly $(p<0.05)$ the one with the lower AIC score was selected, in the opposite situation, the principle of parsimony was applied and the model with lower number of parameters was selected. In all analyses, we controlled for variance heterogeneity among replicates (VarIdent constructor function). The choice of estimation method depended on whether model selection focused on the random structure (restricted maximum likelihood method, REML) or fixed structure (maximum likelihood, ML). For random effects, our variance parameters were tested on the boundary based on $\chi^{2}$ with $\mathrm{df}=1$ (see Pinheiro \& Bates 2000, p. 87). However, there is an argument that a more appropriate approach would be to mix equally two $\chi^{2}$ distributions (Zuur et al. 2009, Galecki \& Burzykowski 2013). This would result in halving our reported p-value given by the LR test (in a $50 \%$ mix). In the statistical output tables, we highlight $\mathrm{p}$-values $<0.10$. Depending on the approach, such p-values could be considered significant at $\alpha=0.05$. For the test of regional scale, the LR test is considered anticonservative unless sample sizes are large: in our case, we indicate when p-values were in the range 0.05 to 0.01 , as they may be considered marginally significant. We also provide REML fitted parameter estimates for the full mixed models in Tables S9 to S12 in the Supplement.

Regional and scale-dependent phenotypic variation

For each phenotypic trait, we evaluated the effect of 'region' (fixed factor) as well as 'location' and 'shore' (random factors); 'shore' was nested within 'location' 
which was nested within 'region'. Region was considered a fixed factor because it represented the levels of coastal chlorophyll (north $=$ low, south $=$ high). The lowest unit of replication was the phenotypic value of a pool of colonisers collected in a specific sampling station within a shore (=within-shore variation). For body size, dry mass, carbon and nitrogen content, there were 2 to 4 replicates per shore. For body size, we ran a further analysis where sampling station was nested within 'shore' and the lowest level of replication was the individuals collected within a station (10 to 20 ind.). For lipids, we considered region and location (but not shores) as factors because sufficient individuals for analyses were in many cases collected in only 1 shore; therefore, we pooled all replicate samples taken at the level of location (2 to 9 replicates location $^{-1}$ ). We used univariate tests after exploring patterns with PCA (based on the variance-covariance matrix).

Variance components (body size, dry mass, elemental carbon and nitrogen) were also calculated through REML fitting, using Statistica ${ }^{\mathrm{R}}$ for graphical representation (here 'region' was considered random as it represents a scale of spatial variation). Tests were run separately for each of the 4 sampling periods (2 sampling periods in each of $2 \mathrm{yr}$ ), as the focus was on spatial patterns. Lack of sufficient data for specific combinations of shores and sampling times precluded direct evaluation of temporal variation in spatial patterns, but such variation was interpreted from differences among test outputs.

\section{Phenotypic traits and chlorophyll}

Average chlorophyll values corresponding to the period when larvae are in the water column (February to April) were calculated in the marine sector within a $30 \mathrm{~km}$ radius around each shore (Fig. 1). The monthly mean was calculated per location by considering all pixels in the 2 circles belonging to each location. We used location averages rather than treating shores separately because averaged values per shore were not independent: circles around shores of the same location show considerable overlap (Fig. 1); in addition, variability in trait values between shores of the same location was very low (see Fig. 2a). We explored relationships between phenotypic traits and chlorophyll using non-linear regression. We did not attempt to fit models that included trip and year as factors because we had a low number of independent estimations of chlorophyll, corresponding to 6 locations.

\section{Phenotypic traits and coastal openness}

Coastal openness was calculated for each shore based on the approach of Burrows et al. (2008). A circle of $50 \mathrm{~km}$ radius was constructed, centred on each location using GIS. The openness of a location was then calculated as the area of open sea encompassed within that circle. For instance, in an idealised straight line coast, openness would correspond to half the surface area of a $50 \mathrm{~km}$ radius circle $\left(\sim 3927 \mathrm{~km}^{2}\right)$. Coastal openness was not significantly correlated with satellite chl $a$ ( $\mathrm{p} \gg 0.05)$, and hence trait responses to openness are independent of those to chlorophyll. Responses to coastal openness were evaluated using general least square models ('gls' function in package 'nlme'), based on shore-averaged values of the studied phenotypic traits. Region and sampling trip were added as orthogonal (fixed) factors, and coastal openness as a covariate.

\section{Swimming larvae vs. colonisers}

Tests comparing dry mass, carbon and nitrogen content of swimming larvae vs. colonisers were run using a mixed model approach ('lme' package). The full model considered region and habitat type (plankton vs. rock) as fixed factors and location (nested in region) as a random factor. The random component also had an interaction term (habitat $x$ location) and a term for variance heterogeneity among combinations of habitat and locations. In this analysis, we did not have replication at the level of shore because we collected planktonic larvae at only one shore per location. Hence, in this case, the differences among 'shore-averaged' values of phenotypic traits represent differences among locations (trait values varied little among shores of the same location; see Fig. 2a). Separate tests were carried out for each sampling trip because larvae could not be collected in sufficient numbers at all combinations of shores and sampling times.

\section{RESULTS}

\section{Scale-dependent patterns of average phenotypic traits in colonisers}

Dry mass, carbon and nitrogen content per individual as well as body size varied mainly at the scale of regions and locations (Fig. 2a). Best models (Table 1) incorporated regional effects (for details of model 


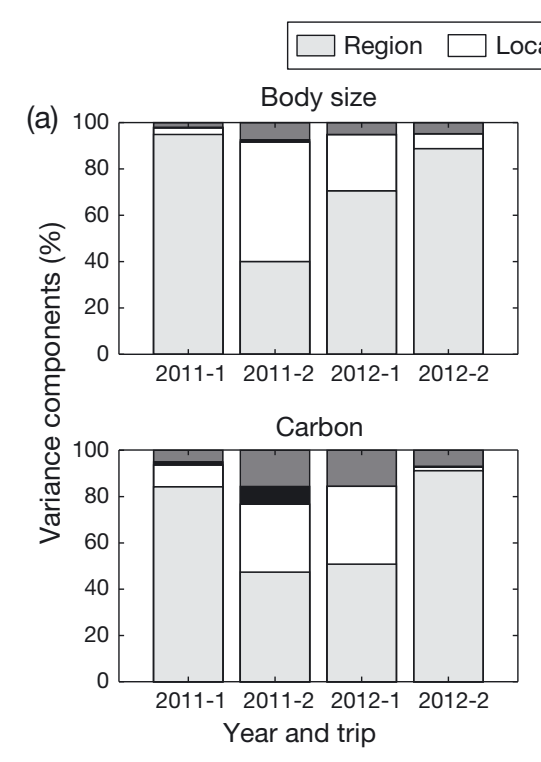

(b)
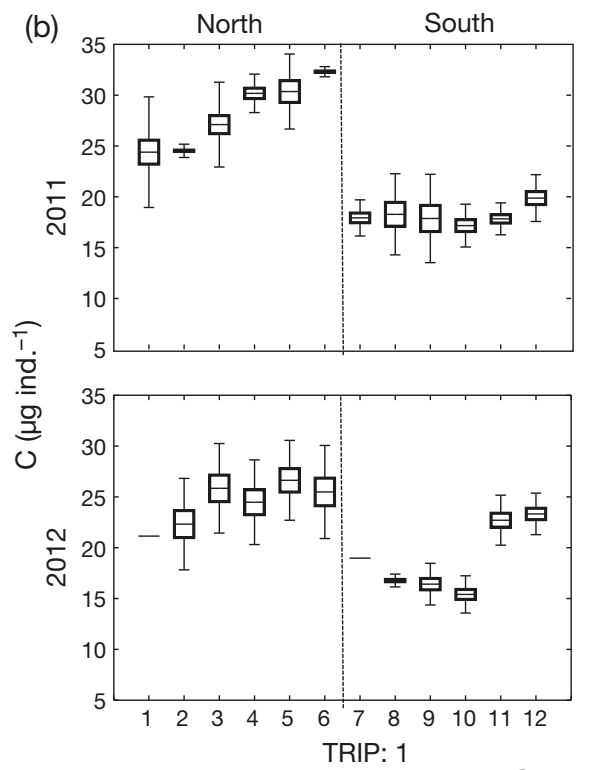

Shore numbers
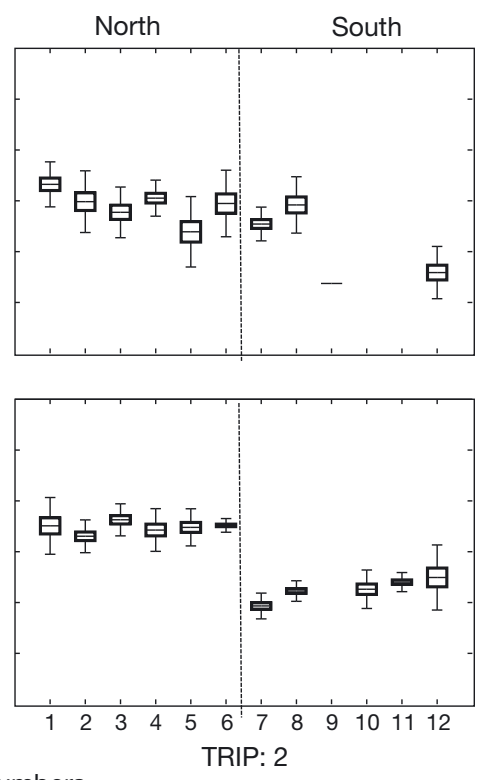

Fig. 2. (a) Partition of phenotypic variance of colonisers by scale (regional, local, shore and within-shores). Phenotype was characterised as body size, dry mass, carbon and nitrogen content. (b) Average carbon content of colonisers (settled non-feeding larvae), by shore (Sites S1 to S12; see Table S1 in the Supplement at www.int-res.com/articles/suppl/m570p141_supp.pdf) in the north and south region of the west coast of Scotland. Boxes: SE; whiskers: 95\% CI. Shores are ordered from north (1) to south (12); names are given in Fig. 1. Samples were collected during 2 trips in 2011 and 2012

selection and tests see Table S2 in the Supplement at www.int-res.com/articles/suppl/m570p141_supp.pdf) and were particularly important in Trip 1 in 2011 and Trip 2 in 2012. At times, regional scale variation amounted to $>40 \%$ in carbon content and $>80 \%$ for total variance in body size. At these sampling times, the average carbon content per individual (Fig. 2b) was 34 to $50 \%$ higher in the north than in the south. Average body size and nitrogen content were also higher in the north region (Figs. S4 \& S5). At times, colonisers from the north also had higher carbon or nitrogen levels calculated as a percentage of dry mass and also more variable $\mathrm{C}: \mathrm{N}$ ratios than those from the south, but these quantities also showed important variation within shores (Tables 1 \& S3, Fig. S6). By contrast, variation among and within shores of the same location was consistently low.

Low within-shore variation in elemental composition and dry mass does not represent low individual variation because we had to pool individuals of each sampling station to quantify these variables. For body size, we were able to partition the within-shore variability into variability between sampling stations and variability among individual larvae collected within each station. This analysis (Fig. S7) showed important and consistent variation among individuals collected within sampling stations ( 26 to $36 \%$ of total variation), i.e. at the smallest spatial scale. In this case, regional scale variability in body size was still important (21 to $71 \%$ ). By contrast, there was consistently low variation among shores or among sampling stations $(<25 \%)$. Hence, variation in body size (and possibly in body mass) occurred mainly at the regional scale (on the order of $100 \mathrm{~km}$ ) and within stations (on the order of $10 \mathrm{~m}$ ).

We did not find evidence of temporal confounding of the significant regional patterns as a consequence of not sampling all locations simultaneously. At the sampling times when regional effects were significant, colonisers collected at southern shores, which were sampled 6 to $7 \mathrm{~d}$ apart (shores 7 and 8 vs. 9 to 12) showed comparable size, body mass and elemental composition (see e.g. Fig. 2b). Also, when regional variation was significant, colonisers from the shores located in different regions but sampled only $2 \mathrm{~d}$ apart (north shores 5 and 6 vs. south shores 7 and 8) showed very different average size, body mass, carbon and nitrogen content. 
Table 1. Summary of best models (lowest AIC value, significance based on likelihood ratio [LR] tests) fitted for station-averaged dry mass (DW), C and N per individual and in percentage, and C:N ratios. Fitting was carried out by sampling period and year. R: region; L: location; S: shore; Ws: within-shore. Ws indicates lack of significant variation of region, location or shore. For details of model selection see Tables S2 \& S3 in the Supplement at www.int-res.com/articles/suppl/ m570p141_supp.pdf. * : significant region effect at $\mathrm{p}<0.01$ after LR test (otherwise, $\mathrm{p}<0.05)$

\begin{tabular}{|cccccccc|}
\hline & Size & DW & C (ind.) & N (ind.) & $\% \mathrm{C}$ & $\% \mathrm{~N}$ & $\mathrm{C}: \mathrm{N}$ \\
\hline 2011 & & & & & & & \\
Trip 1 & $\mathrm{R}^{*}+\mathrm{L}$ & $\mathrm{R}^{*}+\mathrm{L}$ & $\mathrm{R}+\mathrm{L}$ & $\mathrm{R}^{*}+\mathrm{L}$ & $\mathrm{R}^{*}+\mathrm{S}$ & $\mathrm{R}^{*}$ & $\mathrm{R}^{*}+\mathrm{L}$ \\
Trip 2 & $\mathrm{L}$ & $\mathrm{R}+\mathrm{L}$ & $\mathrm{R}+\mathrm{L}$ & $\mathrm{R}+\mathrm{L}$ & $\mathrm{L}$ & $\mathrm{Ws}$ & $\mathrm{L}$ \\
2012 & & & & & & & \\
Trip 1 & $\mathrm{R}^{*}+\mathrm{L}$ & $\mathrm{R}+\mathrm{L}$ & $\mathrm{R}+\mathrm{L}$ & $\mathrm{R}^{*}$ & $\mathrm{Ws}$ & $\mathrm{Ws}$ & $\mathrm{Ws}$ \\
Trip 2 & $\mathrm{R}^{*}+\mathrm{L}$ & $\mathrm{R}^{*}$ & $\mathrm{R}^{*}$ & $\mathrm{R}^{*}$ & $\mathrm{Ws}$ & $\mathrm{R}$ & $\mathrm{R}$ \\
Overall & $\mathrm{R}^{*}+\mathrm{L}$ & $\mathrm{R}^{*}+\mathrm{L}+\mathrm{S}$ & $\mathrm{R}^{*}+\mathrm{L}$ & $\mathrm{R}^{*}+\mathrm{L}$ & $\mathrm{R}+\mathrm{S}$ & $\mathrm{L}$ & $\mathrm{R}^{*}$ \\
\hline
\end{tabular}

Lipids (13\% of dry mass) were dominated by neutral lipids ( $81 \%$ of total lipids), with polar lipids comprising the remaining fraction $(\sim 19 \%)$. Neutral lipids included triacylglycerols (TAGs; $65.5 \%$ of total lipids) and cholesterol (9.2\%) (Table S4). In addition, we found free fatty acids (FFAs; $6.2 \%$ of total lipids). These levels could indicate lipid degradation but we are confident that our methods minimised laboratory biases; higher levels of FFAs have been found in other marine organisms (Takahashi \& Yamada 1976, Tocher \& Seargent 1984).

Multivariate analyses (PCA) of lipid classes (Fig. 3) showed regional segregation on 2 occasions (2011: Trip 1; 2012: Trip 1) from the northern vs. southern populations, which appear to be driven mainly by higher proportions of cholesterol and phosphatidylcholine as well as lower levels of FFA in southern colonisers. Some level of segregation was also found in Trip 2 in 2012 but there was also impor-
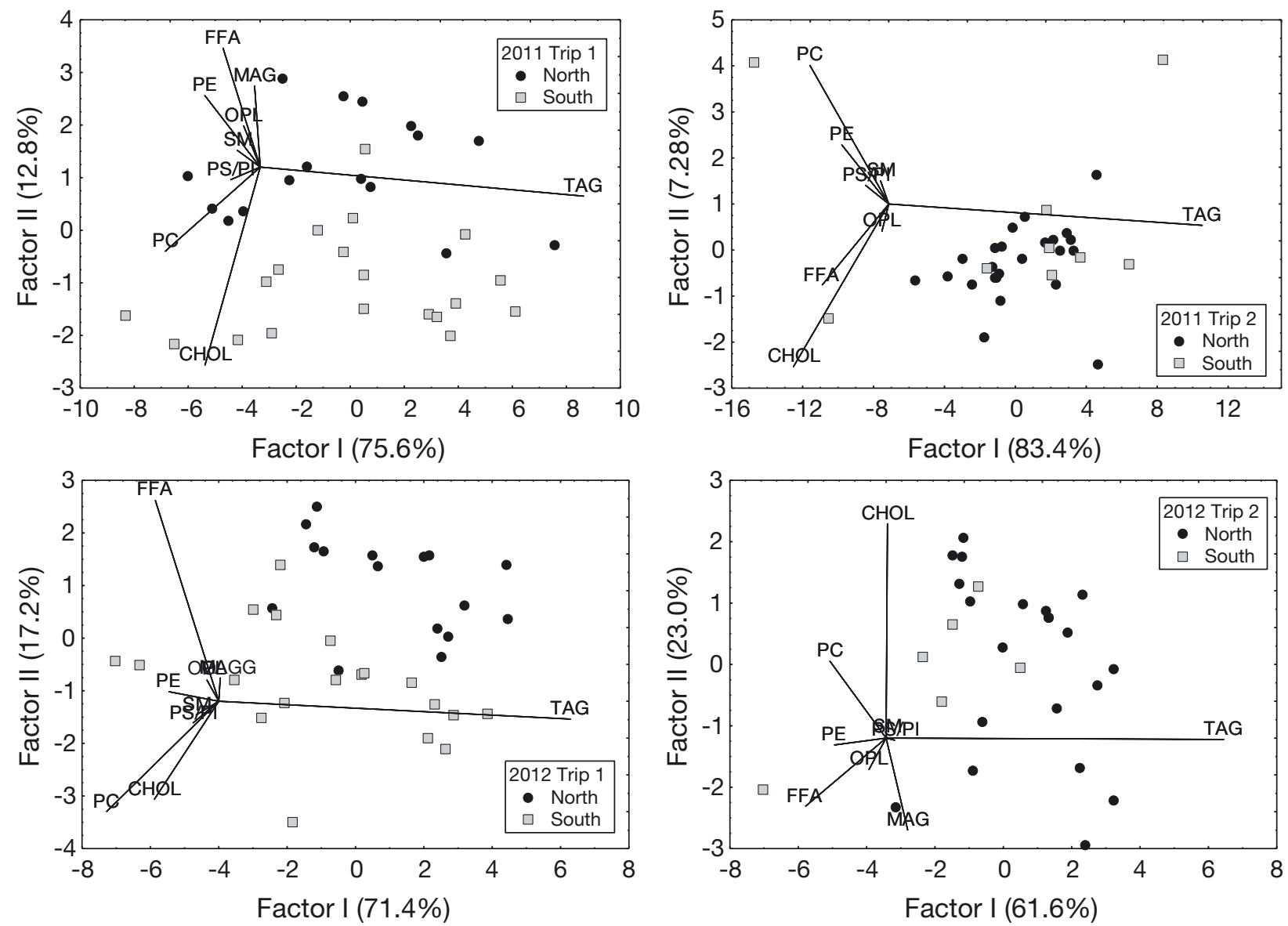

Fig. 3. Principal component analysis of coloniser main lipid classes discriminated by region (south vs. north), sampling trip and year. CHOL: cholesterol; MAG: monoacylglycerol; OPL: other polar lipids; PC: phosphatidylcholine; PE: phosphatidylethanolamine; PS/PI: phosphatidyserine/phosphatidylinositol; SM: sphyngomyelins; TAG: triacylglycerol 
tant scattering of northern samples that indicates a high level of location scale variability. The low number of replicates per location does not permit a strong statistical test of the effects of region and location on lipids; however, best models included regions and locations as the most important scales of variations in cholesterol and polar lipids as a percentage of total lipids. Total lipids and TAGs as a percentage of dry mass varied mainly among locations (Tables 2, S5 \& S6). Total lipids and TAGs per individual varied among locations and, at times, among regions, with higher values in the northern region.

\section{Correlations with chlorophyll levels and coastal openness}

For all sampling times, dry mass, body size, carbon and nitrogen per individual showed a negative correlation with satellite-based chlorophyll values (Fig. 4). These variables showed a non-linear significant decrease $(p<0.05)$ in all trait values with chlorophyll levels.

Dry mass, size and elemental composition responded to coastal openness (Table 3), but the responses were not always consistent (Fig. 5). Carbon
Table 2. Best models (lowest $\mathrm{AIC}_{\boldsymbol{i}}$ significance based on likelihood ratio tests) fitted for station-averaged percentage of total lipids, as a fraction of the dry mass (lipids) and percentage of major lipid classes (TAG: triacylglycerol; Chol: cholesterol; FFA: free fatty acids; Polar: polar lipids) and as a fraction of total lipids. Fitting was carried out by sampling period and year. R: region; L: location; $\mathrm{W}_{\mathrm{L}}$ : within location. Data from Trip 2 was not tested because only 1 location had sufficient colonisers for analyses in the southern region. For details of significance and model selection, see Tables S5 \& S6 in the Supplement at www.int-res.com/articles/suppl/ m570p141_supp.pdf. ${ }^{*}$ : denotes when $\mathrm{p}<0.01$ for the fixed effects after likelihood ratio tests (otherwise, $\mathrm{p}<0.05$ )

\begin{tabular}{|lcccc|}
\hline & $2011-1$ & $2011-2$ & $2012-1$ & All \\
\hline \% Lipids & $\mathrm{W}_{\mathrm{L}}$ & $\mathrm{R}+\mathrm{L}$ & $\mathrm{L}$ & $\mathrm{W}_{\mathrm{L}}$ \\
\% TAG & $\mathrm{W}_{\mathrm{L}}$ & $\mathrm{L}$ & $\mathrm{W}_{\mathrm{L}}$ & $\mathrm{L}$ \\
\% Chol & $\mathrm{R}+\mathrm{L}$ & $\mathrm{L}$ & $\mathrm{R}$ & $\mathrm{L}$ \\
\% FFA & $\mathrm{R}$ & $\mathrm{L}$ & $\mathrm{L}$ & $\mathrm{R}^{*}$ \\
Polar & $\mathrm{R}+\mathrm{L}$ & $\mathrm{L}$ & $\mathrm{R}+\mathrm{L}$ & $\mathrm{L}$ \\
Lipids ind. $^{-1}$ & $\mathrm{~L}$ & $\mathrm{R}+\mathrm{L}$ & $\mathrm{L}$ & $\mathrm{L}$ \\
TAG ind. $^{-1}$ & $\mathrm{~L}$ & $\mathrm{R}+\mathrm{L}$ & $\mathrm{L}$ & $\mathrm{L}$ \\
\hline
\end{tabular}

content responded to coastal openness on only one occasion (Fig. 5a) but body length showed a generally positive response (Fig. 5b). Responses also varied for dry mass, nitrogen content and body size (Figs. S8 \& S9). Neither percentage carbon nor percentage nitrogen showed consistent trends: at times, they correlated negatively or positively with coastal openness. In examining the effect of coastal openness for both years and sampling times, the best models included region as an explanatory factor (Table 3). However, the natural distribution of shores along the Scottish coast (covering a large range of openness in the south, but limited to relatively open shores in the north) makes our interpretation of this regional effect rather tentative. Inspection of graphs, however, showed that traits of colonisers collected in the (open) northern shores differed from those collected in open southern shores.

\section{Traits of swimming larvae vs. colonisers}

The best statistical models included larval type (swimming vs. coloniser), but patterns were not always consistent among all locations or sampling
Fig. 4. Non-linear regression and correlation between main coloniser traits and satellite estimates of chl a by sites (averaged within sectors defined in Fig. 1) 
Table 3. Best general least squares models used to evaluate larval phenotypic responses to coastal openness, and variation among regions and sampling trips. Parameter estimates are given in Fig. 6 and in Figs. S8 \& S9 in the Supplement at www.int-res.com/articles/suppl/m570p141_supp.pdf. O: openness; R: region; T: trip

\begin{tabular}{|ll|}
\hline & Best models \\
\hline Size & $\mathrm{O}+\mathrm{R}+\mathrm{T}+\mathrm{O} \times \mathrm{R}+\mathrm{R} \times \mathrm{T}$ \\
Dry mass & $\mathrm{O}+\mathrm{R}+\mathrm{T}+\mathrm{O} \times \mathrm{T}+\mathrm{P} \times \mathrm{T}$ \\
Carbon & $\mathrm{O}+\mathrm{R}+\mathrm{T}+\mathrm{O} \times \mathrm{T}+\mathrm{P} \times \mathrm{T}$ \\
Nitrogen & $\mathrm{O}+\mathrm{R}+\mathrm{T}$ \\
$\%$ Carbon & $\mathrm{O}+\mathrm{R}+\mathrm{T}+\mathrm{O} \times \mathrm{T}+\mathrm{P} \times \mathrm{T}$ \\
$\%$ Nitrogen & $\mathrm{O}+\mathrm{R}+\mathrm{T}+\mathrm{O} \times \mathrm{P}$ \\
\hline
\end{tabular}

times (Table 4). Nitrogen content per individual was consistently higher in colonisers than in swimming larvae (Fig. 6). However, neither body mass nor carbon content per individual showed consistent responses: colonisers had lower dry mass than swimming larvae in 2011; in 2012 the trend reversed and colonisers showed higher body mass and carbon content (although the trend depended on region).

Carbon content, calculated as a percentage of body mass, was in general higher in colonisers than in swimming larvae in the north (Fig. 6). The balance of carbon and nitrogen was such that in 2012, $\mathrm{C}: \mathrm{N}$ ratios were higher in swimmers than in colonisers. Such trends were consistent with lower proportion of lipid reserves in colonisers than in swimming larvae.

\section{DISCUSSION}

We found critical spatial scales characterised by high variation in nutritional reserves of barnacle larvae colonising rocky shores in West Scotland. The large magnitude of variation in body size and nutritional traits reported here (e.g. 34 to $50 \%$ difference in average carbon content per individual between the north and south regions), calls for approaches to trait-based ecology which consider intraspecific variation (Shipley et al. 2016). Also, specific to our model organism, the information on scale dependence will help to integrate patterns of nutritional reserves into studies of barnacle population dynamics and benthicpelagic coupling.

There are 2 main implications of our results: the first is that under constant rates of larval supply, the flow of carbon associated with larval supply to the shore should be 34 to $50 \%$ higher in the north than in the southwest coast of Scotland. Spatial patterns in energy subsidies are important in generating regional variation in turnover rates of the shore ecosystem (Menge et al. 2003), for example through the flow of energy from prey to local predators (Polis \& Hurd 1996). To our knowledge, studies of energy flow within and between marine ecosystems have not considered the consequences of intra-specific trait variation.
Fig. 5. Linear responses of shore-averaged carbon content and body length of colonisers to coastal openness in individuals collected in different regions during 2 sampling trips in 2011 and 2012 
Table 4. Best mixed models evaluating differences in traits between colonisers and swimming larvae $(\mathrm{H})$ and region $(\mathrm{R})$ as fixed factors and location (L) as random factor. Models consider effects by year and sampling trip, and the overall effects (all years and sampling trips pooled). Detailed statistical results are given in Tables S7 \& S8 in the Supplement at www.int-res.com/articles/ suppl/m570p141_supp.pdf. * : denotes when the fixed effects are significant at $\mathrm{p}<0.01$ after likelihood ratio tests (otherwise, $\mathrm{p}<0.05$ )

\begin{tabular}{|lccccc|}
\hline & $2011-1$ & $2011-2$ & $2012-1$ & $2012-2$ & Overall \\
\hline Dry mass & $\mathrm{R}^{*}+\mathrm{L}: \mathrm{H}$ & $\mathrm{H}^{*}+\mathrm{L}$ & $\mathrm{H}: \mathrm{R}^{*}+\mathrm{L}$ & $\mathrm{H}: \mathrm{R}^{*}$ & $\mathrm{R}^{*}+\mathrm{L}$ \\
Carbon & $\mathrm{R}^{*}+\mathrm{L}: \mathrm{H}$ & $\mathrm{L}$ & $\mathrm{L}$ & $\mathrm{H}: \mathrm{R}$ & $\mathrm{R}^{*}+\mathrm{L}$ \\
Nitrogen & $\mathrm{R}^{*}+\mathrm{L}: \mathrm{H}$ & $\mathrm{H}+\mathrm{L}$ & $\mathrm{H}+\mathrm{R}+\mathrm{L}$ & $\mathrm{H}+\mathrm{R}^{*}$ & $\mathrm{H}^{*}+\mathrm{R}^{*}+\mathrm{L}$ \\
\% Carbon & $\mathrm{H}: \mathrm{R}^{*}+\mathrm{L}$ & $\mathrm{H}: \mathrm{R}^{*}+\mathrm{L}$ & $\mathrm{H}: \mathrm{R}+\mathrm{L}$ & $\mathrm{H}^{*}+\mathrm{R}^{*}+\mathrm{L}$ & $\mathrm{H}^{*}+\mathrm{L}$ \\
\% Nitrogen & $\mathrm{H}+\mathrm{R}^{*}$ & $\mathrm{H}: \mathrm{R}^{*}+\mathrm{L}$ & $\mathrm{H}^{*}+\mathrm{L}$ & $\mathrm{H}^{*}+\mathrm{L}$ & $\mathrm{H}^{*}+\mathrm{H}: \mathrm{L}$ \\
\hline
\end{tabular}

$\sim 2$ to 3 and $\sim 6$ to $8 \mu \mathrm{g}$ ind. $^{-1}$ of lipids respectively; our range was wider $\left(\sim 2\right.$ to $11 \mu \mathrm{g}$ ind..$\left.^{-1}\right)$. Similarly, Jarrett (2003) and Connell (1961) found that cohorts of larger Semibalanus balanoides cyprids resulted in higher post-metamorphic size and growth rates. Furthermore, total lipids and TAGs, which are predictors of settlement success, post-metamorphic growth and survival in other species (Thiyagarajan et al. 2005, Tremblay et al. 2007), varied in Scotland at the scale of locations and regions. The actual impact of the observed varia-

The second implication is that the magnitude of variation in nutritional traits we found is sufficient to impact post-metamorphic performance and recruitment. The wide range of variation found in Scotland (range $\sim 8$ to $32 \mu \mathrm{g} \mathrm{C}$ larva ${ }^{-1}$ ), was also found by others. For instance, Jarrett (2003) found metamorphic success of $\sim 30$ to $>75 \%$ in cohorts of larvae ranging from $\sim 7$ to $16 \mu \mathrm{g} \mathrm{C}$ larva $^{-1}$ (estimated with the oxidation technique). Lucas et al. (1979) found that metamorphic success varied between $<50$ and $100 \%$ with tions in nutritional traits on metamorphic performance will depend on the post-metamorphic environment (Moran \& Emlet 2001, Allen et al. 2008, Marshall et al. 2010). In particular, the food environment experienced by barnacle juveniles (i.e. phytoplankton abundance and chemical composition) has been identified as a modulator of the effect of larval experience on juvenile performance (Thiyagarajan et al. 2005), and correlations between chlorophyll and barnacle size in juvenile $S$. balanoides suggest that


Fig. 6. Average $( \pm \mathrm{SE})$ percent carbon of swimming and settled larvae (colonisers). Each pair of values joined by a line corresponds to a specific location belonging to either the north or south region ( 2 to 3 locations region ${ }^{-1}$ ). Each panel shows data from a specific year and sampling trip (see Table 3 for significant differences effects of larval types) 
regional scale patterns in chlorophyll impact growth (Burrows et al. 2010). Hence, in the north, nutritional reserves are likely to buffer early juveniles from negative effects of low food density. At the finest scale (within shores), nutritional variation is expected to impact performance because larvae with low levels of reserves become less selective and colonise suboptimal microhabitats (Tremblay et al. 2007); thus, the resulting juveniles should show decreased growth and survival. Temporal variation in cyprid traits interacting with environmental variation may also drive the dynamics of recruitment (Torres et al. 2016); such variation can be very important in $S$. balanoides as shown by Pineda et al. (2006), who found only those individuals settling within a narrow time window were able to reach maturity.

Observation of strong scale-dependent variation in multiple traits allows insight into the proximal ecological processes likely to affect trait variation. We hypothesised that at regional scales, larval reserves would correlate positively with chlorophyll as a consequence of the positive effect of food density on growth rates, but instead we found negative correlations. The only pattern consistent with our original hypothesis was, at times, the increased proportion of cholesterol in the southern colonisers. This is likely a consequence of the fact that crustaceans cannot synthesise cholesterol de novo, and grazers rely on conversion from phytosterols assimilated from microalgal food (Martin-Creuzburg \& von Elert 2009). Thus, increased levels of sterols are expected in response to increased phytoplankton density (e.g. Hurtado et al. 2012).

There are a number of potential explanations for the negative correlation found between chlorophyll and larval reserves across our regional study. One is that low food availability in the north could select against smaller larvae, eroding the variance of larval size distributions and thus increasing average body size. However, we examined the standard deviations of body size and found no evidence for this hypothesis (see Fig. S10 in the Supplement at www.intres.com/articles/suppl/m570p141_supp.pdf). Alternatively, larger cyprid size and lower levels of cholesterol in northern Scotland may reflect exposure to reduced temperatures. In $S$. balanoides, cyprid size increases towards colder regions over continental scales (Crisp 1962). In other organisms, cholesterol responds negatively to temperature as part of a mechanism to regulate membrane fluidity (Crockett 1998), and studies in marine species have found seasonal or spatial patterns in cholesterol that are consistent with the existence of such mechanisms
(Parent et al. 2008, Pernet et al. 2008). However, we did not find consistent evidence of latitudinal thermal gradients in the studied area (Fig. S1 in the Supplement). Differences in cyprid size between regions may reflect differences in egg size carried over through the nauplius stages and resulting from, for example, north-south gradients in air temperature. We know that adults from the northern shores produce larger larvae (nauplius I) than those from the south; however, subsequent laboratory experiments (larvae fed monocultures of Skeletonema costatum) showed no evidence of strong carry-over effects of mass of nauplius I on cyprid size (L. Gimenez et al. unpubl. data). By contrast, laboratory experiments with barnacle larvae (West \& Costlow 1987, Hentschel \& Emlet 2000) have shown that cyprid size responds strongly to food and temperature conditions experienced at the mid to end of the naupliar phase. This could point to mechanisms related to food quantity and quality (Barnes 1956, Moyse 1963, Ianora et al. 2004, Caldwell 2009), not revealed by patterns of chl a, explaining the regional pattern in cyprid size and nutritional traits.

Whatever the proximate mechanism, the regional patterns in larval reserves are consistent with an adaptive explanation, whereby larval reserves would compensate for a poor food environment after metamorphosis (e.g. as in coral reef fish; Hamilton et al. 2008). Evolutionary theory predicts that adaptive phenotypic responses should arise when the new environment is predictable (Marshall et al. 2010, Metz et al. 2015) and the gradient in chlorophyll found in West Scotland is predictable over several generations (Fig. S3). Such adaptive processes may be impaired by gene flow (Kawecki \& Stearns 1993, Lenormand 2002) driven by larval dispersal, but larval transport models suggest a high level of larval retention within the fjords and adjacent islands of the west coast of Scotland (Adams et al. 2014), and limited exchange at the spatial scales covered in our study have been found in $S$. balanoides in Canada (Dufresne et al. 2002). Future studies will evaluate whether genetic variation is important at regional scales in Scotland.

At the scale of shores and locations, we found decoupled (=uncorrelated) responses of body size and nitrogen vs. carbon content (nitrogen and carbon are proxies for proteins and lipids respectively). Decoupled responses can occur under variable conditions (Phillips 2006), from the balance of favourable food conditions during the feeding stages (which impact body size and all reserves) vs. costs of substratum search during the non-feeding stage (which 
primarily impact lipid and carbon reserves) (Holland \& Walker 1975, Lucas et al. 1979, Harms 1987, West \& Costlow 1987, Hentschel \& Emlet 2000). The consistent positive response of body size and nitrogen content to coastal openness found in the southern region suggests that conditions at open shores favour naupliar growth. The lack of response of carbon content suggests, by contrast, suboptimal conditions at the cyprid stage. Cyprid larvae may require extended times to reach shores on open coastlines compared to (enclosed) fjords, leading to the burning of lipid reserves. Further decoupled responses were evident when comparing traits of swimming larvae and colonisers as representing different time points in the processes of substratum search and colonization. Successful colonization should be favoured by increased reserves (Tremblay et al. 2007) accumulated in the naupliar phase as lipid and proteins; however, it will also imply that those cyprids successfully settling would have had to burn lipids during substratum search. The overall result is a decoupling of the nitrogen and carbon responses: the average levels of nitrogen should be higher in settlers compared to the swimming cyprids, while the average carbon content may decrease in settlers or may not show any trend. Increased nitrogen content may also reflect increased muscle protein mass (in addition to protein reserves used during metamorphosis) (Lucas et al. 1979) playing an important role in substratum search. Overall, the percentage of lipids in the colonisers collected in Scotland ( 13\% on average) are similar to those reported in Lucas et al. (1979) for $S$. balanoides larvae that spent several days delaying metamorphosis. Hence, costs of substratum search are a likely driver of carbon and lipid reserves in barnacle larvae colonising Scottish shores.

\section{CONCLUSIONS}

We identified regional and within-station scales as those with the highest variation in body size and larval nutritional traits of cyprids of Semibalanus balanoides; i.e. the spatial scales where intraspecific trait variation is most likely to affect recruitment and energy flows across ecosystems. We did not find any satisfactory evidence of a proximate mechanism driving the regional scale patterns in larvae traits. However, our analysis suggests an ultimate (adaptive) mechanism whereby larval nutritional phenotypes will match the requirements for juvenile survival. Decoupling of the responses of larval traits to shoreline morphology and in the patterns of swimming larvae vs. colonisers suggests some selective effect of larval physiological quality (higher total nitrogen content) and costs of habitat search (reduced percent carbon), especially in the north. Our study calls for further research quantifying scale-dependent intraspecific variation in nutritional reserves and other multiple phenotypic traits: this is an important matter if we are to understand the ecological consequences of phenotypic variation.

Acknowledgements. We acknowledge Dr. Joachim Harms (Forschungszentrum Jülich, Rostock-Warnemünde, Germany) for advice at earlier stages of this investigation as well as Dr. Katherine Griffith, Dr. Enrique Gonzalez-Ortegon and Steve Newstead for help during the sampling. Access to the data set will be provided through DASHH data centre, unique identifier: DASSHDT00000343. This research was funded by a Natural Environment Research Council (NERC) grant NEH006702/1 (UK) to S.R.J., L.G., M.T.B. and G.T.

\section{LITERATURE CITED}

Adams TP, Aleynik D, Burrows MT (2014) Larval dispersal of intertidal organisms and the influence of coastline geography. Ecography 37:698-710

Allen RM, Buckley YM, Marshall DJ (2008) Offspring size plasticity in response to intraspecific competition: an adaptive maternal effect across life-history stages. Am Nat 171:225-237

Anger K, Harms J (1990) Elemental (CHN) and proximate biochemical composition and decapod crustacean larvae. Comp Biochem Physiol B 97:69-80

Barnes H (1956) Balanus balanoides (L.) in the Firth of Clyde: the development and annual variation of the larval population, and the causative factors. J Anim Ecol 25:72-84

* Beckerman AP, Benton TG, Lapsley CT, Koesters N (2003) Talkin' 'bout my generation: environmental variability and cohort effects. Am Nat 162:754-767

* Benton TG, Plaistow SJ, Beckerman AP, Lapsley CT, Littlejohns $\mathrm{S}$ (2005) Changes in maternal investment in eggs can affect population dynamics. Proc Biol Sci 272: 1351-1356

Bolnick DI, Amarasekare P, Araújo MS, Bürger R and others (2011) Why intraspecific trait variation matters in community ecology. Trends Ecol Evol 26:183-192

*Besnan EK, Cook B, Hughes SL, Hay SJ, Smith K, Walsham P, Webster L (2015) Seasonality of the plankton community at an east and west coast monitoring site in Scottish waters. J Sea Res 105:16-29

Burrows MT, Harvey R, Robb L (2008) Wave exposure indices from digital coastlines and the prediction of rocky shore community structure. Mar Ecol Prog Ser 353:1-12

* Burrows MT, Jenkins SR, Robb L, Harvey R (2010) Spatial variation in size and density of adult and post-settlement Semibalanus balanoides: effects of oceanographic and local conditions. Mar Ecol Prog Ser 398:207-219

* Caldwell GS (2009) The influence of bioactive oxylipins from marine diatoms on invertebrate reproduction and development. Mar Drugs 7:367-400

Chave J (2013) The problem of pattern and scale in ecology: What have we learned in 20 years? Ecol Lett 16:4-16 
Connell JH (1961) Effects of competition, predation by Thais lapillus, and other factors on natural populations of the marine barnacle Balanus balanoides. Ecol Monogr 31: 61-104

Crisp DJ (1962) The planktonic stages of the cirripedia Balanus balanoides (L.) and Balanus balanus (L.) from north temperate waters. Crustaceana 3:207-221

*Crockett EL (1998) Cholesterol function in plasma membranes from ectotherms: membrane-specific roles in adaptation to temperature. Am Zool 38:291-304

Dufresne F, Bourget E, Bernatchez L (2002) Differential patterns of spatial divergence in microsatellite and allozyme alleles: further evidence for locus-specific selection in the acorn barnacle, Semibalanus balanoides? Mol Ecol 11:113-123

Ellner SP (2013) Rapid evolution: from genes to communities, and back again? Funct Ecol 27:1087-1099

Folch J, Lees N, Sloane-Stanley GH (1957) A simple method for the isolation and purification of total lipids from animal tissues. J Chromatogr A 43:120-126

Galecki A, Burzykowski T (2013) Linear mixed-effect models using R. Springer, Heidelberg

* Giménez L (2010) Relationships between habitat conditions, larval traits, and juvenile performance in a marine invertebrate. Ecology 91:1401-1413

Giménez L, Jenkins SR (2013) Combining traits and density to model recruitment of sessile organisms. PLOS ONE 8: e57849

Hamilton SL, Regetz J, Warner RR (2008) Postsettlement survival linked to larval life in a marine fish. Proc Natl Acad Sci USA 105:1561-1566

Harms J (1987) Energy budget for the larval development of Elminius modestus (Crustacea: Cirripedia). Helgol Mar Res 41:45-67

Hentschel BT, Emlet RB (2000) Metamorphosis of barnacle nauplii: effects of food variability and a comparison with amphibian models. Ecology 81:3495-3508

Holland DL, Walker G (1975) The biochemical composition of the cypris larva of the barnacle Balanus balanoides L. J Cons Int Explor Mer 36:162-165

Hurtado MA, Racotta IS, Arcos F, Morales-Bojórquez E, Moal J, Soudant P, Palacios E (2012) Seasonal variations of biochemical, pigment, fatty acid, and sterol compositions in female Crassostrea corteziensis oysters in relation to the reproductive cycle. Comp Biochem Physiol B 163:172-183

Ianora A, Miralto A, Poulet S, Carotenuto Y and others (2004) Aldehyde suppression of copepod recruitment in blooms of a ubiquitous planktonic diatom. Nature 429:403-407

Jarrett JN (2003) Seasonal variation in larval condition and postsettlement performance of the barnacle Semibalanus balanoides. Ecology 84:384-390

Jenkins SR, Murua J, Burrows MT (2008) Temporal changes in the strength of density-dependent mortality and growth in intertidal barnacles. J Anim Ecol 77:573-584

Kawecki T, Stearns S (1993) The evolution of life histories in spatially heterogeneous environments: optimal reaction norms revisited. Evol Ecol 7:155-174

Kendall MA, Bowman RS, Williamson P (1982) Settlement patterns, density and stability in the barnacle Balanus balanoides. Neth J Sea Res 16:119-126

Lenormand T (2002) Gene flow and the limits to natural selection. Trends Ecol Evol 17:183-189

Levin S (1992) The problem of pattern and scale in ecology. Ecology 73:1943-1967
Levin LA (2006) Recent progress in understanding larval dispersal: new directions and digressions. Integr Comp Biol 46:282-297

* Lucas MI, Walker G, Holland DL, Crisp DJ (1979) An energy budget for the free-swimming and metamorphosing larvae of Balanus balanoides (Crustacea: Cirripedia). Mar Biol 55:221-229

*Marshall DJ, Morgan SG (2011) Ecological and evolutionary consequences of linked life-history stages in the sea. Curr Biol 21:R718-R725

* Marshall DJ, Monro K, Bode M, Keough MJ, Swearer S (2010) Phenotype:environment mismatches reduce connectivity in the sea. Ecol Lett 13:128-140

Martin-Creuzburg D, von Elert R (2009) Ecological significance of sterols in aquatic food webs. In: Arts MT, Brett MT, Kainz MJ (eds) Lipids in aquatic environments. Springer, New York, NY, p 43-64

McLachlan AJ, Ladle RJ (2011) Barriers to adaptive reasoning in community ecology. Biol Rev Camb Philos Soc 86: 543-548

Menge BA, Lubchenco J, Bracken MES, Chan F and others (2003) Coastal oceanography sets the pace of rocky intertidal community dynamics. Proc Natl Acad Sci USA 100: 12229-12234

* Metz J, von Oppen J, Tielbörger K (2015) Parental environmental effects due to contrasting watering adapt competitive ability, but not drought tolerance, in offspring of a semi-arid annual Brassicaceae. J Ecol 103:990-997

Moran A, Emlet R (2001) Offspring size and performance in variable environments: field studies on a marine snail. Ecology 82:1597-1612

Moyse J (1963) A comparison of the value of various flagellates and diatoms as food for barnacle larvae. ICES J Mar Sci 28:175-187

Olsen RE, Henderson RJ (1989) The rapid analysis of neutral and polar marine lipids using double-development HPTLC and scanning densitometry. J Exp Mar Biol Ecol 129:189-197

* Parent GJ, Pernet F, Tremblay R, Sévigny JM, Ouellette M (2008) Remodeling of membrane lipids in gills of adult hard clam Mercenaria mercenaria during declining temperature. Aquat Biol 3:101-109

*Pechenik JA (2006) Larval experience and latent effects: metamorphosis is not a new beginning. Integr Comp Biol 46:323-333

* Pechenik JA, Wendt DE, Jarrett JN (1998) Metamorphosis is not a new beginning. Bioscience 48:901-910

*Pernet F, Tremblay R, Redjah I, Sévigny JM, Gionet C (2008) Physiological and biochemical traits correlate with differences in growth rate and temperature adaptation among groups of the eastern oyster Crassostrea virginica. J Exp Biol 211:969-977

* Phillips NE (2006) Natural variability in size and condition at settlement of 3 species of marine invertebrates. Integr Comp Biol 46:598-604

Pineda J, Starczak V, Stueckle TA (2006) Timing of successful settlement: demonstration of a recruitment window in the barnacle Semibalanus balanoides. Mar Ecol Prog Ser 320:233-237

Pinheiro J, Bates D (2000) Mixed effects models in S and S plus. Springer, New York, NY

Pinheiro J, Bates D DebRoy S, Sarkar D, R Core Team (2015) nlme: linear and nonlinear mixed effects models. R package version 3.1-120. http://CRAN.R-project.org/package= nlme 
Podolsky RD, Moran AL (2006) Integrating function across marine life cycles. Integr Comp Biol 46:577-586

Polis GA, Hurd SD (1996) Linking marine and terrestrial food webs: allochthonous input from the ocean supports high secondary productivity on small islands and coastal land communities. Am Nat 147:396-423

R Core Team (2013) R: a language and environment for statistical computing. R Foundation for Statistical Computing, Vienna

Rainbow PS, Walker G (1977) The functional morphology of the alimentary tract of barnacles (Cirripedia: Thoracica). J Exp Mar Biol Ecol 28:183-206

Rey F, Silva Neto GM, Brandão C, Ramos D and others (2016) Contrasting oceanographic conditions during larval development influence the benthic performance of a marine invertebrate with a bi-phasic life cycle. Mar Ecol Prog Ser 546:135-146

Roughgarden J, Gaines S, Possingham H (1988) Recruitment dynamics in complex life cycles. Science 241:1460-1466

Schreiber S, Rudolf VHW (2008) Crossing habitat boundaries: coupling dynamics of ecosystems through complex life cycles. Ecol Lett 11:576-587

Shipley B, Be Bello F, Cornelissen H, Laliberte E, Laughlin D, Reich P (2016) Reinforcing loose foundation stones in trait-based plant ecology. Oecologia 180:923-931

Sinervo B, Svensson E, Comendant T (2000) Density cycles and an offspring quantity and quality game driven by natural selection. Nature 406:985-988

Sotka EE (2012) Natural selection, larval dispersal, and the geography of phenotype in the sea. Integr Comp Biol 52: 538-545

Takahashi H, Yamada M (1976) Lipid composition of seven

Editorial responsibility: Joseph Pawlik Wilmington, North Carolina, USA species of crustacean zooplankton. Bull Jpn Soc Sci Fish 42:769-776

Thiyagarajan V, Hung OS, Chiu JMY, Wu RSS, Qian PY (2005) Growth and survival of juvenile barnacle Balanus amphitrite: interactive effects of cyprid energy reserve and habitat. Mar Ecol Prog Ser 299:229-237

* Tocher DR, Seargent JR (1984) Analyses of lipids and fatty acids in ripe roes of some Northwest European marine fish. Lipids 19:492-499

Todd PA, Oh J, Loke LHL, Ladle RJ (2012) Multi-scale phenotype-substrate matching: evidence from shore crabs (Carcinus maenas L.). Ecol Complex 12:58-62

* Torres G, Giménez L, Pettersen AK, Bue M, Burrows MT, Jenkins SR (2016) Persistent and context-dependent effects of the larval feeding environment on post-metamorphic performance through the adult stage. Mar Ecol Prog Ser 545:147-160

Tremblay R, Olivier F, Bourget E, Rittschof D (2007) Physiological condition of Balanus amphitrite cyprid larvae determines habitat selection success. Mar Ecol Prog Ser 340:1-8

ํVan Allen BG, Rudolf VHW (2015) Habitat-mediated carryover effects lead to context-dependent outcomes of species interactions. J Anim Ecol 84:1646-1656

West TL, Costlow JD (1987) Size regulation in larvae of the crustacean Balanus eburneus (Cirripedia: Thoracia). Mar Biol 96:47-58

Wiens J (1989) Spatial scaling in ecology. Funct Ecol 3: 385-397

Zuur A, Ieno E, Walker N, Savaliev A, Smith G (2009) Mixed effect models and extensions in ecology with R. Springer, New York, NY

Submitted: November 2, 2016; Accepted: February 2, 2017 Proofs received from author(s): April 10, 2017 